\title{
Images of Slavs in Discourse-World of Brexit
}

\author{
Svetlana L. Kushneruk* \\ Chelyabinsk State University \\ Chelyabinsk, Russian Federation \\ South Ural State Humanitarian Pedagogical University \\ Chelyabinsk, Russian Federation
}

Received 10.10.2020, received in revised form 16.02.2021, accepted 09.04.2021

\begin{abstract}
The paper focuses on the media image construal of the Slavs against the backdrop of the Brexit procedure. The objective of the author is to examine the cognitivediscursive mechanisms of representing the West, East, and South Slav national groups in the British media in the context of Britain's withdrawal. The author employed the cognitive-discursive analysis, integrating advances of European and Russian linguistics. The term "discourse-world of Brexit" is considered to be a conceptually complex discourse-level structure, serving as a background against which the national images stand out. It is argued that images of the Slavs are organized by frames that enable media managers to negatively or neutrally evaluate members and non-members of the European Union. The media frames structuring the national images are systematized. Examples from the news on the web corpus are used to prove that images of the Slavs are discursively constrained and biased. The results might present interest for further investigation of prejudices in the media.
\end{abstract}

Keywords: image, discourse-world, framing, frames, British media, Slavs, Brexit.

The research was funded by RFBR and Chelyabinsk Region, project number 20-412740004.

Research area: philology.

Citation: Kushneruk, S.L. (2021). Images of slavs in discourse-world of Brexit. J. Sib. Fed. Univ. Humanit. Soc. Sci., 14(4), 544-557. DOI: 10.17516/1997-1370-0741.

\footnotetext{
(C) Siberian Federal University. All rights reserved

* Corresponding author E-mail address: Svetlana_kush@mail.ru ORCID: 0000-0003-4447-4606
} 


\title{
Образы славян в дискурсивном мире Брексита
}

\author{
С.Л. Кушнерук \\ Челябинский государственный университет \\ Российская Федераиия, Челябинск \\ Южно-Уральский государственныий \\ гуманитарно-педагогический университет \\ Российская Федерация, Челябинск
}

\begin{abstract}
Аннотация. Исследуется медийная специфика дискурсивного конструирования образов славянских народов в период освещения журналистами проблем Брексита. Цель работы - изучение когнитивно-дискурсивных механизмов репрезентации западных, восточных, южных славян в британских СМИ в контексте выхода Великобритании из Евросоюза. Используется когнитивно-дискурсивный метод и корпусный анализ, интегрирующие достижения европейской и российской лингвистики. Вводится в научный оборот термин «дискурсивный мир Брексита», предлагается его трактовка как репрезентационной структуры. Определяется онтологический статус репрезентационной структуры, служащей фоном, на котором профилируются образы славян. Утверждается, что национальные образы славян организованы фреймами, которые позволяют журналистам преимущественно негативно или нейтрально оценивать членов и не членов Европейского союза. Систематизируются медийные фреймы, структурирующие образы славян в каждой национальной разновидности, обусловленной культурно-языковой принадлежностью. Приводятся доказательства из британского новостного интернет-корпуса, подтверждающие, что образы славян дискурсивно ограничены и в значительной степени идеологизированы. Полученные результаты представляют интерес для дискурс-анализа в аспектах изучения воспроизводства идеологии в зарубежных средствах массовой информации, предрассудков по отношению к славянским народам, а также национальных гетеростереотипов.
\end{abstract}

Ключевые слова: образ, дискурсивный мир, фреймирование, фрейм, британские медиа, славяне, Брексит.

Исследование выполнено при финансовой поддержке РФФИ и Челябинской области в рамках научного проекта № 20-412-740004.

Научная специальность: 10.00.00 - филологические науки.

\section{Introduction}

The pivotal moment of the UK referendum ended up with a victory of the Leave side on 23 June 2016, but it took Great Britain more than three years before it finally stopped being a member of the European Union on 31 January 2020. Numerous aspects of the withdrawal have received much scholarly attention in economics and finance (Doválová et al., 2019; Tien et al., 2019); psychology and sociology (Chandio \& Sah, 2020; Hutchings \& Sullivan, 2019); functional linguistics (Fontaine, 2017); media discourse studies (Meislova, 2019; Mompean \& Valenzuela, 2019; Đurović \& Silaški, 2018; Gheorghiu, 2019; Musolff, 2017; Tincheva, 2019). Some scholars argue that the "levels of prejudice towards 'others' was a factor in the Brexit vote" (Hutchings \& Sullivan, 2019).

The existing papers are mainly Eurocentric, i.e. interpreting Brexit in terms of European values. The problem of the withdrawal has affected both domestic and international 
affairs, shared by many Slavic communities inside and outside Europe. Almost nothing has been found in the current publications on the images of the Slavic nations against the background of Brexit from a non-European perspective.

Slavic national groups include members (Bulgaria, Croatia, Czech Republic, Poland, Slovakia, Slovenia), candidate members (North Macedonia, Montenegro, Serbia), and non-members of the EU (Belorussia, Russia, Ukraine). I argue that the images of Slavs, disseminated by the British media, map on prejudices.

Brexit highlighted the prejudiced attitude toward the Slavic ingroups and outgroups. My concern is to give a discursive account of the image construal from a position of a non-European representative. The paper aims to provide an examination of dominant images of the Slavic national groups in the British media and specify notable frames, structuring them. The inquiry helps better understand the role of Brexit framing in representing images of the Slavs in the context of the withdrawal procedure. It will be shown that some attitudes are neutral, while the majority is negative.

\section{Cognitive-Discursive Approach and World Modelling Theory Background}

The cognitive-discursive approach seeks to take into account the communicative, cognitive, and social factors in analyzing media discourse. The methodological bases of the study have been elaborated through integrating ideas, proposed by van Dijk (2000, 2006, 2013, 2016), Wodak (2006), Wodak and Meyer (2001), Gavins and Lahey (2016), Tincheva (2018, 2019), Boldyrev (2017), Cherniavskaya (2013), Beller and Leerssen (2007), Scheufele (1999), Tewksbury and Scheufele (2009), Kunczik (2002, 2016). The cognitive-discursive approach, used to investigate the images of Slavs in the British media, is based on the following assumptions:

- the context of language use is crucial for discourse studies (van Dijk, 2000; Wodak \& Meyer, 2001; Wodak, 2006);

- discourse structures can not be isolated from cognitive phenomena (Boldyrev, 2017;
Cherniavskaia, 2013; Tincheva, 2019; Wodak, 2006);

- language is essentially "world-building" (Gavins \& Lahey, 2016);

- discourse is structured by ideologies as belief systems (van Dijk, 2013, 2016);

- discourse-world is socially, politically and culturally situated (Gavins \& Lahey, 2016);

- the media never reflect social practices disinterestedly (Fairclough, 1989);

- media frames organize social reality (Entman, 1993; Kunczik, 2016; Sheufele, 1999);

- media discourses disseminate images and prejudices (Kunczik, 2016).

Principally, discourse structures need to be described in terms of cognitive notions, such as knowledge and concepts that are formed in the mind and serve as an interface between an individual and social practices (Tincheva, 2019; van Dijk, 2016). Discourse studies gain significantly in case cognitive aspects are integrated with social and communicative (Wodak, 2006: 180). Discourse studies are not limited to one method. According to van Dijk, they include: "analysis of the lexicon, syntax, local and global meaning (semantics), speech acts, and other relations with the context (pragmatics), style, rhetoric, argumentation, narrative structures, or other conventional organization of discourse, on the one hand, and quantitative corpus analysis, ethnography, participant observation, or psychological experiments, among other methods, on the other hand" (Van Dijk, 2013: 176).

Discourse analysis may prove more reliable if qualitative techniques are combined with the quantitative in a "mixed-methods" perspective, which "enables researchers to provide a stronger evidence base for studying a research problem than either quantitative or qualitative research alone" (Qaiwer, 2016: 68). The present study is designed to use a mixed methodology that includes a cognitive-discursive approach in combination with a corpus approach to assessing the Brexit-related reality.

Reality is given by people through representations, which include words, pictures, sounds, stories, and "stand for" ideas (Hartley, 2002). Based on the signifiers they encounter, people create mental representations. The role 
of texts is crucial for invoking mental representations (Gavins \& Lahey, 2016).

I have introduced the term "representational structures". It denotes mental constructs, textualized in discourse, which relate to the processes and results of reality presentation, and vary in degrees of conceptual complexity. The main ones are discourse-world and textworld. (Tincheva, 2018: 298).

The term discourse-world refers to "the real-world situation in which language occurs" (Gavins \& Lahey, 2016: 2). I have devised a broader perspective to study discourse-worlds within World Modelling Theory. It is a branch within discourse linguistics, which relies on concepts, proposed by discourse analysts and cognitive linguists, to explore mental and linguistic representations of reality in discourse for the purposes of communication (Kushneruk, 2018, 2019: 267-271).

I have defined world-modelling as structuring information about reality and its representation in discourse in accord with the objectives of communication. I use the term discourse-world of Brexit (henceforth DW of Brexit) to denote a rich, discourse-level conceptual structure, encoded by media managers and decoded by readers, in an aggregate of Brexit-related texts, produced in the context of Britain's withdrawal from EU.

I also take into account the imagological perspective of the term representation, which designates "the ways in which texts provide images of the world" (Beller \& Leerssen, 2007: 415). Images are disseminated by the media, which shape readers' perception of national groups, focusing on particular aspects of their life, behaviour, etc. that draw on the existing stereotypes and prejudices and form the new ones.

\section{Imagological Background and Statement of the Problem}

The term image was used in Western philosophy (Hartley, 2002: 107). The complexity of an image stems from the interrelation of different semantic categories that constitute it. In literary studies, it is defined as "the mental or discursive representation or reputation of a person, group, ethnicity or "nation"” (Beller \& Leerssen, 2007: 342). In communication and media studies, it is considered on the individual level, encompassing visual, communicative, behavioural aspects; on the cultural level, as "the alienation of personal attributes for semiotic purposes" (Hartley, 2002: 107-108), and on the media level, it is associated with public representation of politicians, entertainers, celebrities (Hurcombe, 2016). Linguistically, the basic meaning components of a word image are: (1) a visual representation of something; (2) a mental picture or impression of something; (3) a popular conception projected especially through the mass media (https://www.merriam-webster.com/dictionary/image).

In recent years, divergent researches have been carried out on various aspects of image within imagology. Beller postulates that imagology "studies the origin and function of characteristics of other countries and peoples, as expressed textually, particularly in the way in which they are presented in works of literature, plays, poems, travel books and essays" (Beller \& Leerssen, 2007: 7). With time, the imagological perspective has acquired a broader scope. Imagology presents a viable approach to tackle questions in a wider circle of humanities, including media discourse analysis. What image of "them" we construct, crucially depends on the choice of media managers who form people's expectations about national groups.

One cannot brush aside factual information when assessing individual or group images. I follow Curtis, pointing out that statements about people are "inherently comparative in nature" (Curtis, 1998: xxix). Image representations are more problematic in the media discourse, which is as much about testable facts as about misleading interpretations. It is the question of a selective choice of the junks of factual information on the part of journalists who are powerful agents of discourse (Dijk, 2006). One of my claims is that national images of the Slavs are "silhouetted" in the DW of Brexit but their representations are discursively constrained.

\section{Materials and Methods}

The data are situated in the context of Brexit as covered in the British media throughout the year 2019 and January 2020. The situat- 
edness criterion is pivotal for cognitive-discursive analysis as it tends to account for the role of political, social and ideological factors in reality representation. The dataset was intentionally compiled. The contexts were searched and retrieved from an online corpus News on the $W e b$ that contains about 9 billion words from web newspapers and magazines from 2010 to the present time.

For the research, I created a personalized collection based on a combination of the keyword "Brexit" and information about the texts, namely, by timespan (1 Jan 2019 - 31 Jan 2020) and country (Great Britain). These parameters limited the sample to 3090 texts (total of 3186549 words).

In the corpus of texts collected for the study, I searched for instances of words that nominated any Slavic national groups. By the Slavic national groups, I mean peoples of Central and Eastern Europe, including Russians, Ukrainians, and Belorussians (East Slavs), Pol- ish, Czechs, Slovaks (West Slavs), Bulgarians, Serbians, Croatians, Macedonians, and Slovenians (South Slavs).

Any context containing the following tokens was considered eligible for inclusion in the virtual corpus (in alphabetical order): Belarus, Bulgaria (Bulgarian, Bulgari), Croatia (Croatian), Czech Republic (Czech, Czechoslovakia, Czechs, Czechia), Macedonia (Macedonian), Montenegro, Poland (Polish, Poles, Pole), Russia (Russian, Russians), Serbia (Serbian), Slovenia (Slovenian), Ukraine (Ukrainian, Ukrainians). I also analyzed the use of the names of political leaders such as Caputova, Duda, Grabar-Kitarovic, Putin, Vucic, Zelenskiy, Zeman. The total number of contexts was calculated and classified by groups of related languages. The following results are systematized in Table 1.

Table 1 demonstrates the distribution of references to different Slavic groups in the Brexit-related virtual corpus. In an aggregate

Table 1. Distribution of tokens in the Brexit-related corpus

\begin{tabular}{|c|c|c|}
\hline Subgroup of Slavic languages & Tokens & Total number of contexts -712 \\
\hline West Slavs & & 252 \\
\hline \multirow[t]{6}{*}{ POLISH } & & 184 \\
\hline & Poland & 82 \\
\hline & Polish & 73 \\
\hline & Poles & 15 \\
\hline & Pole & 13 \\
\hline & Duda & 1 \\
\hline \multirow[t]{7}{*}{$\mathrm{CZECH}$} & & 40 \\
\hline & Czech & 23 \\
\hline & Czechoslovakia & 6 \\
\hline & Czechs & 4 \\
\hline & Czech-born & 4 \\
\hline & Czechia & 1 \\
\hline & Zeman & 2 \\
\hline \multirow[t]{5}{*}{ SLOVAK } & & 28 \\
\hline & Slovakia & 20 \\
\hline & Slovak & 4 \\
\hline & Slovaks & 1 \\
\hline & Slovakian & 1 \\
\hline
\end{tabular}




\begin{tabular}{|c|c|c|}
\hline \multicolumn{3}{|c|}{ Continued Table } \\
\hline Subgroup of Slavic languages & Tokens & Total number of contexts -712 \\
\hline & Caputova & 2 \\
\hline East Slavs & & 390 \\
\hline \multirow[t]{10}{*}{ RUSSIAN } & & 332 \\
\hline & Russia & 161 \\
\hline & Russian & 91 \\
\hline & Russians & 14 \\
\hline & Russia-focused & 1 \\
\hline & Russian-related & 1 \\
\hline & Russian-owned & 1 \\
\hline & Russian-occupied & 1 \\
\hline & Russian-backed & 1 \\
\hline & Putin & 61 \\
\hline \multirow[t]{5}{*}{ UKRAINIAN } & & 55 \\
\hline & Ukraine & 27 \\
\hline & Ukrainian & 11 \\
\hline & Ukrainians & 8 \\
\hline & Zelenskiy & 9 \\
\hline \multirow[t]{2}{*}{ BELARUSIAN } & & 3 \\
\hline & Belarus & 3 \\
\hline South Slavs & & 70 \\
\hline \multirow[t]{4}{*}{ CROATIAN } & & 24 \\
\hline & Croatia & 15 \\
\hline & Croatian & 8 \\
\hline & Grabar-Kitarovic & 1 \\
\hline \multirow[t]{4}{*}{ BULGARIAN } & & 21 \\
\hline & Bulgaria & 15 \\
\hline & Bulgarian & 5 \\
\hline & Bulgari & 1 \\
\hline \multirow[t]{4}{*}{ SERBIAN } & & 10 \\
\hline & Serbia & 6 \\
\hline & Serbian & 3 \\
\hline & Vucic & 1 \\
\hline \multirow[t]{3}{*}{ SLOVENIAN } & & 6 \\
\hline & Slovenia & 4 \\
\hline & Slovenian & 2 \\
\hline \multirow[t]{3}{*}{ MACEDONIAN } & & 6 \\
\hline & Macedonia & 5 \\
\hline & Macedonian & 1 \\
\hline \multirow[t]{2}{*}{ MONTENEGRIN } & & 3 \\
\hline & Montenegro & 3 \\
\hline
\end{tabular}


of texts about Brexit, the UK media most frequently employ references to the East Slavic ethnic groups $(54.8 \%)$. Then come the West Slavs (35.4\%) and the South Slavs (9,8\%).

\section{Discussion: Images of Slavs}

Terms "country image" and "national image" are used synonymously: "National image, then, can be defined as the cognitive representation that a person holds of a given country, what a person believes to be true about a nation and its people" (Kunczik, 2002: 49). I will concentrate on verbal and textual codifications to reveal the main Brexit-related frames, constituting national images.

Within media communication, framing has to be treated as a social constructivist phenomenon. I claim that DW of Brexit serves a discursive reference space, against which country images are profiled. Profiling has to do with the gestalt perception principle and the figure/ground phenomenon (Tsur, 2009: 238).

National image representations are structured by media frames, i.e. cognitive and communicative schemas, used for presenting news (Gamson \& Modigliani, 1987; Gheorghiu, 2019; Tewksbury \& Scheufele, 2009). Entman points out that "to frame is to select some aspects of a perceived reality and make them more salient in a communicating text, in such a way as to promote a particular problem definition, causal interpretation, moral evaluation, and/or treatment recommendation" (Entman, 1993: 52). I will show that media frames are embedded in DW of Brexit.

\section{The East Slavs}

DW of Brexit is an ideologically biased construct. The choice of frames (hereafter highlighted through bold italics) structuring it is driven both by journalistic codes, political and ideological factors. The classification proposed in the paper relies on revealing discourse meanings, primarily signalled by topics, propositions, modalities, actor descriptions, and rhetorical means (van Dijk 2013). Among the East Slavs, tokens relating to the Russian (85\%) are the most frequent, tokens of the Ukrainian rise to $14 \%$, only $1 \%$ of occurrences allude to the Belarusian. In DW of Brexit, the image of Russia is the most controversial.

The coverage of Brexit is biased by the assessment of Russia as a political aggressor. Against the backdrop of a Brexit landscape, framing encourages readers to perceive Russia in several aspects: Putin's Russia, Russia as regime, Russia as superpower, Russia as threat, Russia as adversary, Russia as enactor of warfare.

The Independent, known to have advocated the UK remain, represents Russia in close association with President Putin as a strong leader, who has a decisive role in manipulation and is not going to "take the pressure off" (1), (4):

(1) Putin managed to manipulate the Russian people into his antagonised theory through fuelling acrimony towards the west. This has been always a key tactic, which has proved efficient in turning ordinary citizens - more or less compelled as they are to consume constant, malicious propaganda - to believe that Brexit can turn the wheel in Russia's favour. (The Independent, 8.01.2019).

Negative meanings about Russia are emphasized by predicates and arguments with negative semantics, conveyed by the words manipulate, antagonised, acrimony, malicious, propaganda, and the metaphorical use of fuel, consume, turn the wheel.

Russia's political image is often evoked by Russia as superpower frame:

(2) It should be clear by now that Brexit is not just a local British dilemma. $<\ldots>$ This is due to its strategic and economic impact on Europe's stability, Britain's position on the world's stage, and how Brexit will help Russia to rise again as a superpower in a new bipolar order. (The Independent, 8.01.2019).

In (2), a deontic modal expression It should be... connotes serious problems, in case Russia becomes a superpower.

In DW of Brexit Russia as threat frame is the most visible. It renders preconceived ideas about Russia's possibilities of inflicting damage to Brexit procedure:

(3) Seely is as absorbed as anyone in the day-to-day drama of Brexit, and he's been increasingly vocal in recent months about the 
threats posed by a revanchist Russia. (Politics Home, 10.10.2019).

In (3), Russian activity is interpreted in terms of revanchism. In other contexts the frame is realized through propositions that relate to Russia's interference in Brexit: "Russia used Twitter bots and trolls 'to disrupt' Brexit vote." (The Times, 8.12.2019).

It seems that the frame Russia as threat does not contribute to any newly-coined image, but is retrieved from a repository of images, associated with the USSR period (e.g. "Soviet occupation of Eastern Europe", "dissolution of the Union of Soviet Socialist Republics"):

(4) Russian President Vladimir Putin has predicted the downfall of the European Union in a chilling warning comparing the bloc's demise to the collapse of the Soviet Union. (Express, 21.11.2019).

In (3) and (4), history-related facts are selectively used to reinforce the existing critical-negative evaluation. References to Soviet Russia serve as a lesson, intended to darken political colours. A highly negative image-making becomes even more pronounced due to the use of rhetorical means, such as epithets and metaphors. E.g.:

(5) But the Kremlin's interest in Scotland is not simply military, rather it is more insidious. In the Scottish nationalist movement, Russia sees a proxy to weaken and divide the UK, which has long been a thorn in the Kremlin's side. (The Scotsman, 16.03.2019).

In (5), Russia's interest is characterized as insidious. Negative connotations arise from the metaphorical use of the word proxy, attributed to the nationalist movement. Negative image is also created by the metaphor "a thorn in the Kremlin's side", meaning "a constant or persistent cause of annoyance". It embeds the perception of Russia as a powerful opponent and a serious danger.

Image construal of Russia is often triggered by the co-activation of several frames:

(6) Third, an existential threat to British democracy is cyberwarfare by Putin's regime in Russia. The DCMS select committee found that Russia has already engaged in "unconventional warfare" against British voters. (https:// blogs.lse.ac.uk/brexit/2019/09/10/).
In (6), the frames Russia as threat, Russia as enactor of warfare and Russia as regime are simultaneously co-activated by explicit forms of direct-negative evaluation, such as "an existential threat", "cyberwarfare by Putin's regime", and "unconventional warfare". The lexeme regime has a meaning "a government, especially an authoritarian one" (https://www. lexico.com/). Negatively-charged frames invite readers to perceive the country as an adversary.

The frame Russia as adversary has got numerous explicit manifestations:

(7) Adversaries include but are not limited to Isil, a resurgent al-Qaeda, Russia and China. $<\ldots>$ If cyber is MI6's hottest area, it is Russia that is its greatest state adversary. (The Telegraph, 15.02.2019).

In (7), Russia is put at the same rank as jihadist groups, having violent ideologies and claiming religious authority over all Muslims, such as Isil and al-Quaeda.

Russia as enactor of warfare frame is realized through overt accusations of waging warfare (cyberwarfare, cyberattacks, hybrid warfare) and striving to dominate European countries. E.g.:

(8) The Kremlin has already developed a sophisticated and well-coordinated arsenal of techniques to divide and dominate small European countries. (The Scotsman, 16.03.2019).

In (8), the frame exerts a substantial influence on deteriorating Russian political image due to explicitly represented propositional meanings and associations about the growing influence of the country.

The peripheral aspects of Russia's image are presented in relation to economy and society. The transported nation-image of Russia is also highly negative. It is structured by the frame Russia as raw materials' source:

(9) Putin believes the post-Cold War international order is unfair. This idea is not new or his alone, but it has assumed heightened importance as Russia's oil-fuelled economic growth rates of the early 2000s have been replaced by recession and stagnation. (The Scotsman, 16.03.2019).

In (9), the negativization of the image is explicit. Recession and stagnation are about a decline in economic activity. The metaphor 
oil-fuelled highlights the country's vital dependence on oil.

The image of Russia, carried forward by the British media, draws on facts about social problems in the country, the main being suicide and demography:

(10) "Russia's suicide rate is one of the highest in the world," and in 2010 "one in ten villages in Russia had fewer than ten inhabitants". (The Spectator, 30.01.2019).

In (10), the frame Russia's social problems is activated, which contributes to a gloomy image of the country with an unfavorable social atmosphere.

Readers of the British press are exposed to the frame Russian people. In DW of Brexit, a set of characterizations is limited to evoking mental representations solely about oligarchs:

(11) For we were in Anthracite <...> a once-rundown area which is now the go-to mecca for chic restaurants and boutiques and flats you can't even think about unless you've met $\mathrm{Mr}$ Russian Oligarch. (The Express, 6.04.2019).

Context (11) is taken from the article about a spot worth visiting during "dark days in Brexit Britain". The use of antonomasia serves to highlight how much oligarchs are associated with Russians. English-language dictionaries, reflecting current usage of the word oligarch, automatically select examples about Russians (see, for example, https://www.merriam-webster.com/dictionary/oligarch).

In DW of Brexit, the image of the Ukrainians is discursively represented by three frames. Ukraine as victim of Russia frame typically manifests in the articles about the war in Donbass. A complex image of a poor country, victimized by the Soviet Union, which eventually gained independence, and is now led forward by a president, unsuccessful in eradicating corruption, is regularly pushed forward. It is often due to the co-activation of frames, such as Ukraine as a weak country and Ukrainian president:

(12) Zelenskiy's promise to fight corruption has resonated with Ukrainians who are fed up with politics as usual in a country of 42 million people that remains one of Europe's poorest nearly three decades after winning indepen- dence from the Soviet Union. (https://uk.news. yahoo.com/).

It is emphasized that the current president is a comedian without prior political experience: "Ukrainians vote on Sunday in the second round of an election that could thrust a comedian with no prior political experience into the presidency of a country at war and wanting transformational change". (Yahoo news, 21.04.2019).

The Belarusians are almost ignored in the media coverage of Brexit with one exception. The Independent mentions a refugee from Belarus, arriving in England (The Independent, 2.02.2019), which is an implication of a hot topic of immigration.

\section{The West Slavs}

Among the West Slavic national groups, tokens relating to the Polish, constitute the largest one $(73 \%)$, less frequent are tokens of the Czech (16\%), occurrences of the Slovak (11\%) form the minority. All three countries are members of the EU, they are primarily conceptualized in relation to EU politics. Clusters of ideas are framed to guide readers' understanding of their political interests in Brexit. It is quite predictable that national images are structured by the frames Poland as EU member, Czechia as EU member, Slovakia as EU member. These frames are set by linkages to chief politicians, responsible for making decisions in each country.

Poland as $\boldsymbol{E U}$ member frame is realized through quotes, attributed to D. Tusk, K. Szymański, A. Duda, A. Rzegocki, expressing their concern on Polish national security after Brexit. The frame Czechia as $\boldsymbol{E U}$ member reduces the country political image to A. Babis and M. Zeman (The Independent, 27.06.2019). Slovakia as EU member frame helps understand the role of the first female president $\mathrm{Z}$. Čaputová (Politico, 21.08.2019).

Brexit coverage features idiosyncratic frames. In DW of Brexit, the image of the Polish is mainly limited to several interpretative schemas, presenting Poland's economic activity and social life. The most emblematic frames are Migration, Poland's economy, Employment, Polish people. 
Via media frame Migration, the readers have come to comprehend that thousands of Polish nationals are concerned about their settled status after British withdrawal. This frame is textualized by the representation of statistics about Polish communities. The metaphor surge ("the migrant surge from Poland") is used in the media as a powerful semantic-rhetorical means that makes a biased ideological representation of the Polish. Together with overtly negative qualifications of the Poles, the frame contributes to a preconceived hetero-image construal:

(13) David Cameron thought that Remain was a certainty because of the belief among those advising him that people wouldn't "vote themselves poorer because they don't like the Poles living next door". (The Independent, 12.04.2019).

The context exemplifies a semantic strategy of polarization between "us" and "them" (van Dijk 2000). "They" stand for the residents of the UK, and "the Poles" stand for the collective image of immigrants from Poland. Thus, a hetero-image, induced by the Independent, has a negative slant and implies hostile evaluation.

An auto-image has acquired a positive evaluative bias. For instance, Poland's economy frame in the Brexit-supportive press is driven by the intentions of Polish politicians to build up an attractive image of the country. In an interview, A. Rzegocki has been quoted saying:

(14) "Poland and the Polish economy is growing, life standards are improving - they are much different compared with five to 10 years ago." (Grimsby Telegraph, 18.09.2019).

In (14), Polish nationals living in the UK are encouraged by the ambassador to get back to "their homeland".

Employment frame highlights types of work Polish people do for British companies. These are mainly menial jobs in agriculture, construction, hospitality, food and fish processing, fields and factories: "Ninety-nine per cent of the people in the fields and the factories were Polish." (The Independent, 2.02.2019).

The frame Polish people reflects socially shared beliefs about their culture and be- haviour. Against the backdrop of Brexit, some of them are formulated as stereotypes:

(15) "Apparently it's de rigueur for Polish drinkers who allegedly don't get hangovers and cautious Germans who believe that a pickled herring or two will keep the aches and shakes away."'(The Herald Scotland, 16.03.2019).

In (15), two stereotypes about the Poles are revealed. Firstly, Polish people are drinkers, secondly, they don't get hangovers.

In DW of Brexit an image of the Czech and the Slovak become evident due to the frame Czechoslovakia. References are regular in the press, advocating the Remain side. It seems explicable in terms of ideological polarization. The frame Czechoslovakia makes salient the benefits of being a member of the EU for the Czech and the Slovak in contrast to their united country history:

(16) Austria, Hungary, the Czech Republic and Slovakia are all members of the European Union, enjoying the benefits of the single market and the free movement of people. $<\ldots>$ Away from all the arguments about Brexit, that huge historical fact about the EU is how it has helped transform the fortunes of its members. It helped the western ones recover from the Second World War, and the east-central ones to rebuild after the Cold War. (The Independent, 26.06.2019).

In (16), the current situation in the EU is implicitly compared to the times of the socialist camp, associated with communism as a plague of the $20^{\text {th }}$ century in Eastern and Central Europe. It is presupposed that the EU has given the Czech Republic and Slovakia protection and support within the cosy "European family".

\section{The South Slavs}

Among the South Slavic national groups, tokens of the Croatian (34.3\%) are the most numerous, less frequent are tokens of the Bulgarian $(30 \%)$, occurrences of the Serbian constitute twice a smaller part (14.3\%), references to the Slovenian and the Macedonian are even $(8.6 \%)$, tokens of the Montenegrin are the fewest (4.2\%).

Journalists frame issues about the political activity of member states (Croatia, Bulgaria, 
Slovenia), concerned about the exodus of Brexit. Frames Croatia as $\boldsymbol{E} U$ member, Bulgaria as $\mathrm{EU}$ member, Slovenia as EU member render viewpoints of politicians who represent the countries' interests (A. Plenkovic, President K. Grabar-Kitarović, B. Borisov, M. Sarec):

(17) The Slovenian prime minister has not been shy in criticising the actions of the UK over the past two and a half years of Brexit negotiations. In March he said: "We are concerned about what the European Union's future will be not the UK's." (The Week, 8.05.2019).

In (17), the frame Slovenia as $\boldsymbol{E} \boldsymbol{U}$ mem$\boldsymbol{b e r}$ is activated by indirect and direct-quotative uses. The frame encourages audiences to make connections between the withdrawal procedure and the prime minister's worries about the EU-related future.

Though the Balkan Peninsula is marked by ethnic diversity of South Slavic peoples, in DW of Brexit, they are represented by the frame Balkan countries, which tends to project a "collective" victimized image:

(18) Paul Stronski highlights in his paper "Russia's game in the Balkans" that the Kremlin's influence in the Western Balkans is geared towards undermining the countries' hopes of joining the European Union and NATO (The Express, 23.11.2019).

In (18), the image of a victim is enhanced by the threat Russia poses to all Eastern Europe. Arguably, such an image is rooted in postwar Yugoslavia. The frame Yugoslavia is primarily evoked in the Remain-supportive press:

(19) Yugoslavia's a good prism through which to see Brexit Britain and the rotund philanderer. Under the Tories, a terrible Brexit will also mean that the country falls apart. (The Guardian, 25.11.2019).

Context (19) reflects the pro-European position, purporting that Britain's departure from the EU is a gross mistake. The allusion evokes the image of Boris Johnson, being an ardent proponent of Brexit. The frame Yugoslavia contributes to organizing public opinion in polarized terms through the contrast of the current situation in Europe and the historical period when peoples in the Balkans suffered from ethnic divisiveness and political upheaval. It suggests that the united Europe is good, and Yugoslavia has brought about some bad experience:

(20) The promise of European Union membership has long been dangled before Balkan states as a tonic that could help to heal the scars of the Yugoslav wars. (The Times, 21.12.2019).

In (20), empathy is accorded to the images of the Balkan states by means of a metaphor of a healing tonic, implying that EU membership for candidate states is supposed to be not only refreshing, but making them well again after a Yugoslav turmoil.

\section{Conclusion}

The notion of DW of Brexit denotes a complex discourse-related conceptual structure, textualized in the media texts about Brexit. DW of Brexit is a representational structure, against which mental portraits of the East, West and South Slavic peoples are profiled. In DW of Brexit, framing is reduced to a number of noteworthy concepts, characteristic of a nation in the context of a political process. The basic frames pre-determining the perception of the Slavs in the British media discourse have politics, economics and society as source domains.

It has been taken into account that Slavic peoples fall into groups, depending on their related languages and the criteria of membership in the EU. Within DW of Brexit, images of those who are members of the EU are generally framed around the perspectives of an after-Brexit future and national interests in the gradually changing European home, being reorganized by Brexit initiatives. A number of idiosyncratic frames have been found out, which reflect biased social attitudes to the Slavs. Eurocentric evaluation of the Slavs is primarily negative, arguably because they belong to outgroups.

Ideological polarization reaches its apogee in the discursive representation of the Eastern European peoples, scaling from overt deprecation of Russians, to the negative and neutral characterization of Ukrainians and Belarusians. The reading public is invited to perceive Russia as an external aggressor, having supernatural power of influencing Brexit. The Ukrainian is valorized either negatively or neutrally. 
In DW of Brexit, the most salient image of the West Slavs is that of the Polish. It is obviously less negative as compared to the East Slavs, but tends to reveal prejudices about people's behaviour and social impetus in the context of Brexit. Historical flashbacks are typical strategies of representing the Czech and the Slovak.

The relevant news frames, organizing images of the South Slavs are the Balkan countries and Yugoslavia. The former projects an image of the Balkan countries, represented as a single whole in spite of their independent political status and decades, passed after the dissolution of Yugoslavia. In the Brexit-supportive press, the named strategy of polarization is adopted by media managers to highlight a possible collapse of the EU, in case of Britain's departure. It seems that the collective image of the Balkan countries is deeply embedded in the mental models of Europeans and because of it finds regular expression in the media.

Preconceived views, organized by frames, determine what people observe and attribute to national images. In the context of Brexit, the images of the Slavs are biased. Most post-communist countries are marked by negative stereotyping. The research has presented a tentative attempt to induce change of negatively-charged images. The author hopes it might provide bases for transcending ethnocentrism, reducing national arrogance, a better understanding of peoples and improving their relations in the global community.

\section{References}

Abrams, D., Houston, D.M. (2006). Equality, diversity and prejudice in Britain: results from the 2005 national survey: report for the cabinet office equalities review. DTI London.

Beller, M., Leerssen, J. (eds) (2007). Imagology. The Cultural construction and literary representation of national characters. A critical survey. Amsterdam/New York, $492 \mathrm{p}$.

Boldyrev, N.N. (ed.) (2017). Interpretatsiia mira viazyke [World Interpretation in Language]. Tambov, Publishing House of TSU named after G. R. Derzhavin, 450 p.

Chandio, M.M., Sah, M. (2020). Brexit sentiment analysis: changing opinions about Brexit and UK. In Intelligent computing paradigm and cutting-edge technologies, available at: https:/www.researchgate.net/ publication/338350281_Brexit_Twitter_Sentiment_Analysis_Changing_Opinions_About_Brexit_and_ UK Politicians. DOI: 10.1007/978-3-030-38501-9 1

Cherniavskaia, V.Y. (2013). Lingvistika teksta. Lingvistika diskursa [Text linguistics. Discourse linguistics]. Moscow: Flinta: Nauka, 208 p.

Curtis, M. (1998). Introduction to the transaction edition. In Lipman, W. Public opinion: with a new introduction by Michael Curtis. Transaction Publishers: New Brunswick (USA) and London (UK), xi-xxxvi.

Đurović, T., Silaški, N. (2018). The End of a Long and Fraught Marriage: Metaphorical Images Structuring the Brexit Discourse. In Metaphor and the Social World, 8 (1), 25-39. DOI: https://doi.org/10.1075/ msw.17010.dur

Doválová, G., Majzlíková Stracová, E., Hošoff, B. (2019). Brexit - the Visegrad Countries’ perspective. In Ekonomický časopis, 67 (č. 10), 1013-1034.

Entman, R.M. (1993). Framing: Towards clarification of a fractured paradigm, In Journal of Communication, 43, 51-58. DOI: https://doi.org/10.1111/j.1460-2466.1993.tb01304.x

Fairclough, N. (1989). Language and Power. London: Longman, 259 p.

Fontaine, L. (2017). The early semantics of the neologism BREXIT: A lexicogrammatical approach. In Functional Linguistics, 4:6, 1-15. DOI: 10.1186/s40554-017-0040-X

Gamson, W.A. and Modigliani, A. (1987). The changing culture of affirmative action. In Braungart, R.G., Braungart, M.M. (eds.) Research in political sociology, 3, 137-177. Greenwich, CT: JAI Press.

Gavins, J. (2007). The Text World Theory: An Introduction. Edinburgh Univ. Press, 193 p.

Gavins, J., Lahey, E. (eds). (2016). World Building: Discourse in the Mind. Bloomsbury, 296 p.

Hartley, J. (2002). Communication, cultural and media studies. The key concepts. Routledge: Taylor \& Francis Group: London and New York, 262 p. 
Gheorghiu, O. C. (2019). Brexit framing in British media, MCDSARE 2019. Available at: https://www. researchgate.net/publication/336265546_BREXIT_FRAMING_IN_BRITISH_MEDIA

Hurcombe, E. (2016). The Making of a Captain: the Production and projection of a political image on the Tony Abbott Facebook page. In Communication, Politics and Culture, 49 (1), 19-38.

Hutchings, P.B., Sullivan, K.E. (2019). Prejudice and the Brexit vote: a tangled web. In Palgrave Communications, 5:5. Available at: https://rdcu.be/b3rNY

Kunczik, M. (2002). Globalisation: News media, images of nations and the flow of international capital with special reference to the role of rating agencies. In The Journal of International Communication, 8, 3979. DOI: $10.1080 / 13216597.2002 .9751921$

Kunczik, M. (2016). Images of nations and international public relations. New Jersey, $346 \mathrm{p}$.

Kushneruk, S.L. (2018). Razvitie teorii kognitivno-diskursivnogo miromodelirovaniia za rubezhom i v Rossii [The development of cognitive-discourse world-modelling theory in European and Russian linguistics]. In Voprosy kognitivnoy lingvistiki, 4: 115-125. Available at: http://discourseworld.ru/ DOI: https://doi. org/10.20916/1812-3228-2018-4-115-125

Kushneruk, S.L. (2019). World-modelling in advertising discourse: pragmatic aspects. In Calidoscópio, 17 (2), 263-281. Available at: http://discourseworld.ru/ DOI: https://doi.org/10.4013/cld.2019.172.03

Meislova, M.B. (2019). Brexit Means Brexit - or Does It? The Legacy of Theresa May's Discursive Treatment of Brexit. In The Political Quarterly, 90 (4). Available at: https://www.researchgate.net/publication/336417317_Brexit_Means_Brexit-or_Does_It_The_Legacy_of_Theresa_May's_Discursive_Treatment of Brexit

Mompean, J.A., Valenzuela, J. (2019). Brexit means Brexit: a constructionist analysis. In Complutense Journal of English Studies, 27: 1-37.

Musolff, A. (2017). Truths, lies and figurative scenarios - Metaphors at the heart of Brexit. In Journal of Language and Politics, 16 (5), 641-657. DOI: 10.1075/jlp.16033.mus.

Qaiwer, S.N. (2016). A Study of Identity Construction in Political Discourse. In Thesis submitted to the University of Nottingham for the Degree of Doctor of Philosophy. Available at: https://www.researchgate. net/publication/309607807_A_study_of_identity_construction_in_political_discourse

Sheufele, D.A. (1999). Framing as a theory of media effects. In Journal of Communication, 49 (1), 103-122.

Tewksbery, D. and Sheufele, D.A. (2009). News Framing Theory and Research, available at:

https://www.researchgate.net/deref/http\%3A\%2F\%2Fdx.doi.org\%2F10.4324\%2F9780429491146-4

Tien, N.H., Bien, B.X., Vu, N.T., Hung, N.T. (2019). Brexit and risks for the world economy. In International Journal of Research in Finance and Management, 2 (2), 99-104.

Tincheva, N. (2018). Discourse-world profiling expressions: contrasting data from British and Bulgarian political speeches. In Language Close Up, (297-317). Sofia: Sofia University Press. Available at: https:// www.researchgate.net/publication/331198543_DISCOURSE_WORLD-PROFILING_EXPRESSIONS CONTRASTING_DATA_FROM_BRITISH_AND_BULGARIAN_POLITICAL_SPEECHES

Tincheva, N. (2019). "Brexit means..." UK vs. continental online-media users and English-language metaphoric conceptualizations. In Journal of Language and Politics, 18:6, 848-869.

Tsur, R. (2009). Metaphor and figure-ground relationship: comparisons from poetry, music, and the visual arts. In Brône, G., Vandaele, J. (eds). Cognitive Poetics: goals, gains and gaps, (237-277). Berlin, New York: Mouton de Gruyter.

Van Dijk, T. (2000). Ideology and Discourse: A Multidisciplinary Introduction. Available at: http:// www.discourses.org/OldBooks/Teun\%20A\%20van\%20Dijk\%20-\%20Ideology\%20and\%20Discourse.pdf

Van Dijk, T. (2006). Discourse, context and cognition. In Discourse Studies, 8 (1), 159-177.

Van Dijk, T. (2013). Ideology and discourse. In Freeden, M., Tower Sargent, L., Stears, M. (eds). The Oxford Handbook of Political Ideologies (175-196). Oxford University Press.

Van Dijk, T. (2016). Sociocognitive discourse studies. In Richardson, J., Flowerdew, J. (eds). Handbook of Discourse Analysis. Routledge, available at: http://www.discourses.org/OldArticles/Sociocognitive\%20 Discourse\%20Studies.pdf 
Wodak, R. (2006). Mediation between discourse and society: assessing cognitive approaches in CDA. In Discourse Studies, 8 (1), 179-190.

Wodak, R., Meyer, M. (eds). (2001). Methods of critical discourse analysis. London. Thousand Oaks. New Delhi. SAGE Publications, 200 p. 